\title{
Postharvest Characteristics of Canaan Fir and Fraser Fir Christmas Trees
}

\author{
Ricky M. Bates, ${ }^{1}$ James C. Sellmer, and David A. Despot \\ Department of Horticulture, The Pennsylvania State University, University \\ Park, PA 16802
}

\author{
Additional index words. Abies balsamea var. phanerolepis, Abies fraseri, xylem pressure \\ potential, needle retention
}

\begin{abstract}
Needle retention, xylem pressure potential and overall quality of canaan fir (Abies balsamea var. phanerolepis (L.) Mill.) and fraser fir (Abies fraseri (Pursh) Poir.) Christmas trees were evaluated over a 40-day display period. Cut trees were stored outdoors for 24, 48 , or 96 hours, and half the trees had a $2.5-\mathrm{cm}$ section trimmed from the basal portion of the stem, before placement in water at an indoor display room. Controls were placed in water immediately after harvest. Xylem pressure potentials and overall quality were similar for both species except for trees stored 96 hours. Untrimmed canaan fir dried to $-2.4 \mathrm{MPa}$ and was rated below average by the end of the display period compared to -1.3 MPa and a good quality rating for fraser fir. Needle retention and color characteristics were excellent across all treatments for fraser fir during the entire display period. Needle loss for canaan fir began relatively soon during display, generally increased across all treatments, and was highly variable. In addition, quality of some canaan fir trees decreased as needles turned brown, but did not shed during the display period. Tree water status alone did not completely account for loss of needles and quality in canaan fir; the need exists to identify seed sources with better postharvest characteristics.
\end{abstract}

The United States annually uses about 35 million live Christmas trees. Postharvest quality of cut trees is an important concern of growers, wholesalers, retailers and consumers. Christmas tree postharvest quality deteriorates over time and is a function of water status (Chastagner, 1986). Common postharvest quality problems include premature needle drop, poor foliage color, fragrance loss, reduced branch flexibility and increased susceptibility to fire (Hinesley, 1984). Conifers used as cut Christmas trees vary in their rate of drying following harvest, and their capacity to maintain freshness during display (Seiler, et al., 1988). Drying rates vary widely depending on vapor pressure deficit, temperature, and light regime (Hinesley and Snelling, 1997). Because of its excellent postharvest quality characteristics, fraser fir [Abies fraseri (Pursh) Poir.] has become one of the most important tree species grown in the eastern U.S. for use as a cut Christmas tree. Fraser fir loses water slowly, has a high damage threshold, retains its needles well when dry, and is quite durable in the postharvest environment (Mitcham-Butler et al., 1988). Fraser fir is in higher demand compared to other species grown in the eastern U.S. and acreage is increasing (Tompkins, 2000). However, expansion of fraser fir production is limited on poorly drained sites because of its susceptibility to certain root rotting pathogens (Sidebottom, 2001)

In recent years, interest has developed in the use of canaan fir [Abies balsamea var. pha-

Received for publication 22 Nov. 2003. Accepted for publication 3 Mar. 2004. We acknowledge the Pennsylvania Christmas Tree Growers Association for supporting this research.

${ }^{1}$ To whom reprint requests should be addressed; e-mailrmb30@psu.edu. nerolepis (L.) Mill.] as a Christmas tree in the eastern U.S. Canaan fir is similar in appearance to fraser fir. Grower experience suggests that canaan fir is less susceptible to the soil borne pathogens that limit the production range of fraser fir (Brown, 1998). Consequently, there is increased interest in growing canaan fir as an alternative to the more site-demanding fraser fir. Little is known, however, concerning the postharvest handling of canaan fir. The following study was undertaken to compare postharvest quality characteristics of canaan fir with fraser fir. We examined moisture status, current-season needle retention and overall tree quality.

\section{Materials and Methods}

In total, 28 canaan fir and 28 fraser fir trees of uniform vigor and density, ranging in height from 1.5 to $2.1 \mathrm{~m}$, were selected in a commercial growers field near Boalsburg, $\mathrm{Pa}$. (Centre County, elevation $370 \mathrm{~m}$ ). Trees had been grown under conditions of uniform fertility, appeared free of insect and disease damage, had at least three age classes of live foliage, and were U.S. No. 1 grade according to USDA standards (USDA, 1989). The fraser fir seed source was Roan Mountain, N.C., and the canaan fir seed source was Canaan Valley, W.Va. Eight canaan fir and eight fraser fir were harvested on 15, 17, and 18 Dec. 2000, and 4 canaan fir and 4 fraser fir were harvested on 19 Dec. for a total of 56 harvested trees. Trees remained outside and unbaled to simulate sales lot storage conditions. Ambient high and low temperatures averaged 13 and $5^{\circ} \mathrm{C}$, respectively, and relative humidity averaged $45 \% \pm 4 \%$, during the $96-\mathrm{h}$ drying treatment. Trees were laid in a single layer on the ground in rows unprotected from rain and wind for the
0-, 24-, 48-, or 96-h storage treatments. On 19 Dec. 2000, trees were baled and transported in a closed truck to the postharvest display room on 19 Dec. 2000. Before placement indoors, a 1.25 - to $2.5-\mathrm{cm}$ section was trimmed from the base of the trunk on four trees of each species from the 24-, 48-, and 96-h storage duration treatments. All trees were drilled before placement on a 4.7-L center-peg tree stand. Less than $2 \mathrm{~h}$ elapsed from the time of harvest to display for trees of the 0-h storage duration treatment. Trees were displayed in a $534-\mathrm{m}^{3}$ postharvest display room at the Russell E. Larsen Research Center and maintained under continuous standard fluorescent lighting at $48 \% \pm 5 \%$ relative humidity $(\mathrm{RH})$ and 20.0 $\pm 5^{\circ} \mathrm{C}$. During display the water level in the stand was always maintained above the base of the tree. Moisture status $(\Psi)$ was measured with a pressure chamber (PMS Instruments, Corvallis, Ore.) at $0,1,2,4,8,15,20$, and $25 \mathrm{~d}$ during display using four 10 to $12 \mathrm{~cm}$ lateral stems from each tree. Needle loss data were obtained at day $0,7,14,28$, and 35 by randomly selecting representative branches and gently rubbing two fingers over current season needles during display. The extent of current season needle loss was evaluated on a 0 to 10 scale, where $0=$ none, $1=1 \%$ to $10 \%, \ldots, 10$ $=91 \%$ to $100 \%$ loss. Each tree was evaluated subjectively for overall quality and needle color at $0,10,20,30$, and $40 \mathrm{~d}$ during display and rated on a 1 to 5 scale where $5=$ excellent, 4 $=\operatorname{good}, 3$ = fair, 2 = below average, $1=$ poor, unacceptable.

\section{Results and Discussion}

Canaan fir and fraser fir differed in moisture retention, current season needle loss and overall tree quality. Fraser fir generally outperformed canaan fir in the postharvest environment and canaan fir exhibited higher variability for measured attributes.

Canaan and fraser fir trees cut immediately before placement in water had an average $\Psi$ of -1.5 and $-1.2 \mathrm{MPa}$, respectively (Fig. 1). Trees cut and stored for 24 and $48 \mathrm{~h}$ dried rapidly to -2.1 to $-3.2 \mathrm{MPa}$ before placement in water. All trees, except the 96-h storage treatment, rehydrated to -1.0 MPA or higher within $4 \mathrm{~d}$ of being placed in water, indicating that most of the water stress associated with sales lot storage and the warm, dry climatic conditions before harvest had been alleviated. Xylem pressure potential never exceeded -1.2 MPa for the 0,24 , or 48-h storage treatments for either species throughout the remainder of the display period.

Both canaan fir and fraser fir cut $96 \mathrm{~h}$ before display dried to an average $\Psi$ of -3.3 to $-3.6 \mathrm{MPa}$ (trimmed and untrimmed) (Fig. 1). Trimmed canaan fir $\Psi$ for trees stored $96 \mathrm{~h}$ rose from $-3.6 \mathrm{MPa}$ to $-1.0 \mathrm{MPa}$ within $4 \mathrm{~d}$ of placement in water and remained above -1.2 $\mathrm{MPa}$ thereafter. Untrimmed canaan fir in the 96-h treatment rehydrated more slowly than the trimmed canaan fir and had average $\Psi$ of -1.7 $\mathrm{MPa}$ after $4 \mathrm{~d}$ in water. However trees began to dry through the remainder of the display period to a final $\Psi$ of $-2.4 \mathrm{MPa}$. Trimmed and 
untrimmed fraser fir stored $96 \mathrm{~h}$ rehydrated more rapidly than canaan fir and maintained higher $\Psi$ throughout the display period. At the end of the display the 96-h, untrimmed treatment, fraser fir had a $\Psi$ of $-1.3 \mathrm{MPa}$ compared to $-2.4 \mathrm{MPa}$ for canaan fir.

Fraser fir needle retention was excellent across all treatments and trees had only minimal needle loss (Fig. 2). By the end of the experiment, needle loss was less than $3 \%$ and $<7 \%$ for the 96-h untrimmed and 24-h untrimmed treatments, respectively. The degree of needle loss on canaan fir generally increased for all treatments during the display period, but was highly variable. Trees stored for $96 \mathrm{~h}$ before placement in water showed no needle loss at the beginning of the experiment. After 35 $\mathrm{d}$ on display however, trimmed trees in the 96-h treatment exhibited between $21 \%$ to $30 \%$ needle loss, whereas untrimmed trees had about $5 \%$ needle loss (Fig. 2). During the first $14 \mathrm{~d}$ on display, needle loss for canaan fir in all treatments was between $0 \%$ and $10 \%$. After $28 \mathrm{~d}$ on display the 96-h trimmed, 48-h untrimmed, and 24-h trimmed and untrimmed treatments all exhibited needle loss $>10 \%$. Needle loss in canaan fir began relatively soon during display, with some trees beginning to shed green needles within $5 \mathrm{~d}$.

Overall quality of fraser fir was excellent to good throughout the 40-d display period for all treatments, whereas canaan fir was good to below average after $40 \mathrm{~d}$. After $20 \mathrm{~d}$ all fraser fir trees were rated 4.75 or higher while no canaan fir treatments received a rating above 4.5. Fraser fir stored for $96 \mathrm{~h}$ remained above 4.0 after $40 \mathrm{~d}$ on display. Canaan fir trees placed in water immediately $(0 \mathrm{~h})$ and within $24 \mathrm{~h}$ (trimmed and untrimmed) rated good to excellent after $40 \mathrm{~d}$; trees stored for $48 \mathrm{~h}$ were rated as fair. All canaan fir trees stored for $96 \mathrm{~h}$ decreased in quality from good to fair within the first $10 \mathrm{~d}$ on display, and were rated as below average by the end of the experiment. This finding might indicate that some trees had dried beyond the damage threshold. The damage threshold is the water content below which a cut tree experiences irreversible damage which can contribute to needle discoloration and premature needle loss before or after rehydration (Hinesley and Snelling, 1991). Published $\Psi$ values for damage thresholds are $-4.0 \mathrm{MPa}$ for fraser fir (Hinesley, 1984), $-3.5 \mathrm{MPa}$ for douglas fir (Montano and Proebsting, 1985) and -3.0 MPa for eastern white pine (Seiler et al., 1988). Canaan fir trees stored for $96 \mathrm{~h}$ dried to $-3.6 \mathrm{MPa}$ before placement in water. These low $\Psi$ values for canaan fir stored 96 $\mathrm{h}$ correspond to low overall quality ratings but did not consistently coincide with needle retention trends for individual trees among the same treatments.

Quality of cut Christmas trees is impacted by needle retention as well as foliage color. In this study, canaan fir needle color was more variable and inconsistent than fraser fir, and also deteriorated noticeably over time among certain trees, contributing to lower overall quality ratings. Slight differences in needle color characteristics were evident at the onset of the experiment. Canaan fir needles were paler
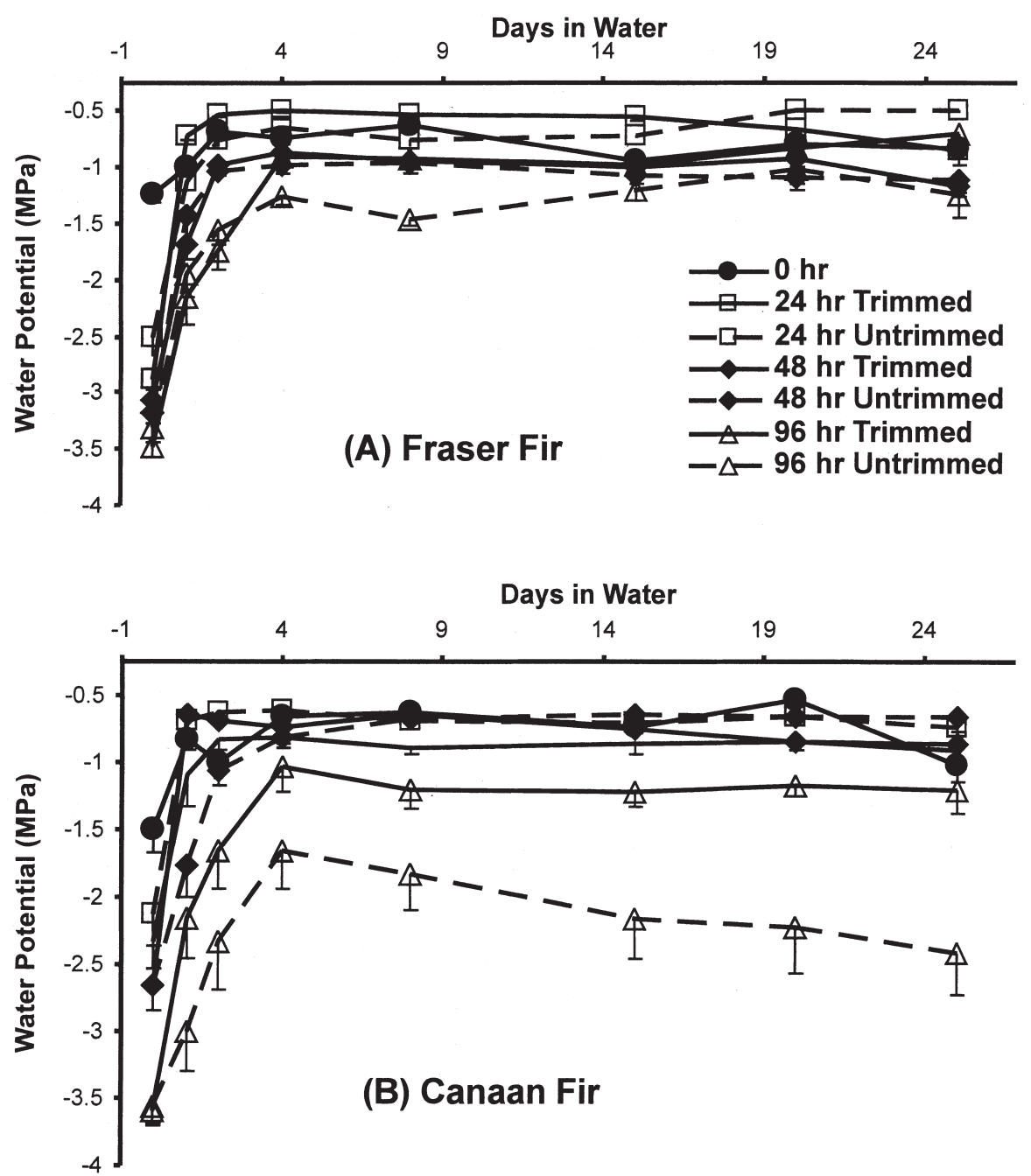

Fig. 1. Changes in xylem pressure potential after rehydrating fraser and canaan fir trees in water after trees were stored outdoors under ambient conditions for $0,24,48$, or $96 \mathrm{~h}$. Bars represent SE of four replications.

green or exhibited a yellowish hue compared to the deeper green fraser needles. Canaan fir needles also turned brown on some trees in the 96-h treatment but did not drop during display. Needle loss from canaan fir seemed to be independent of changes in needle color. In contrast, fraser fir retained its dark green to blue-green color in addition to excellent needle retention characteristics throughout the display period.

Current recommendations for stem trimming Christmas trees include the removal of a 1- to 2-cm thick disk perpendicular to the basal portion of the stem before displaying the tree in water (Chastagner and Hinesley, 2000). The ability to rehydrate after cutting decreases with time, and differs by species. In our study, stem trimming appeared to influence xylem pressure potential only in the trees stored for $96 \mathrm{~h}$ (Fig. 1), and did not appear to affect the overall quality of fraser fir.

Overall, the canaan fir used in these studies had inferior needle retention characteristics and tree quality compared with fraser fir. However, the data suggests that drying alone does not completely account for loss of needles and quality in canaan fir, as some dry trees exhibited good needle retention. Research with canaan fir and other species suggests that needle retention is a highly hereditary characteristic (Chastagner et al., 2003; Hinesley and Snelling, 1997). It may therefore be possible to identify canaan fir seed sources that possess better needle retention traits. Thus, the postharvest quality of canaan fir can be improved through selection and breeding.

\section{Literature Cited}

Brown, J.H. 1998. Nitrogen fertilization of a canaan Valley seed source of Balsam fir. Ohio State Univ., Wooster, Agr. Res. Dev. Ctr. Spec. Circ. 159-98.

Chastagner, G.A. 1986. Effect of postharvest moisture stress on the keeping qualities of douglas-fir Christmas trees. HortScience 21:485-486.

Chastagner, G., K. Riley, and J. Brown. 2003. Identification of canaan fir trees with superior needle retention. 6th Intl. Christmas Tree Res. and Ext. Conf., 14-19 Sept. 2003. Kanuga Conf. Ctr., Hendersonville, N.C. (in press).

Chastagner, G.A. and L.E. Hinesley. 2000. Maintaining moisture levels in cut Christmas trees. Amer. Christmas Tree J. 44:10-16.

Hinesley, L.E. 1984. Measuring freshness of cut fraser fir Christmas trees. HortScience 19:860-862.

Hinesley, L.E. and L.K. Snelling. 1991. Vapor 

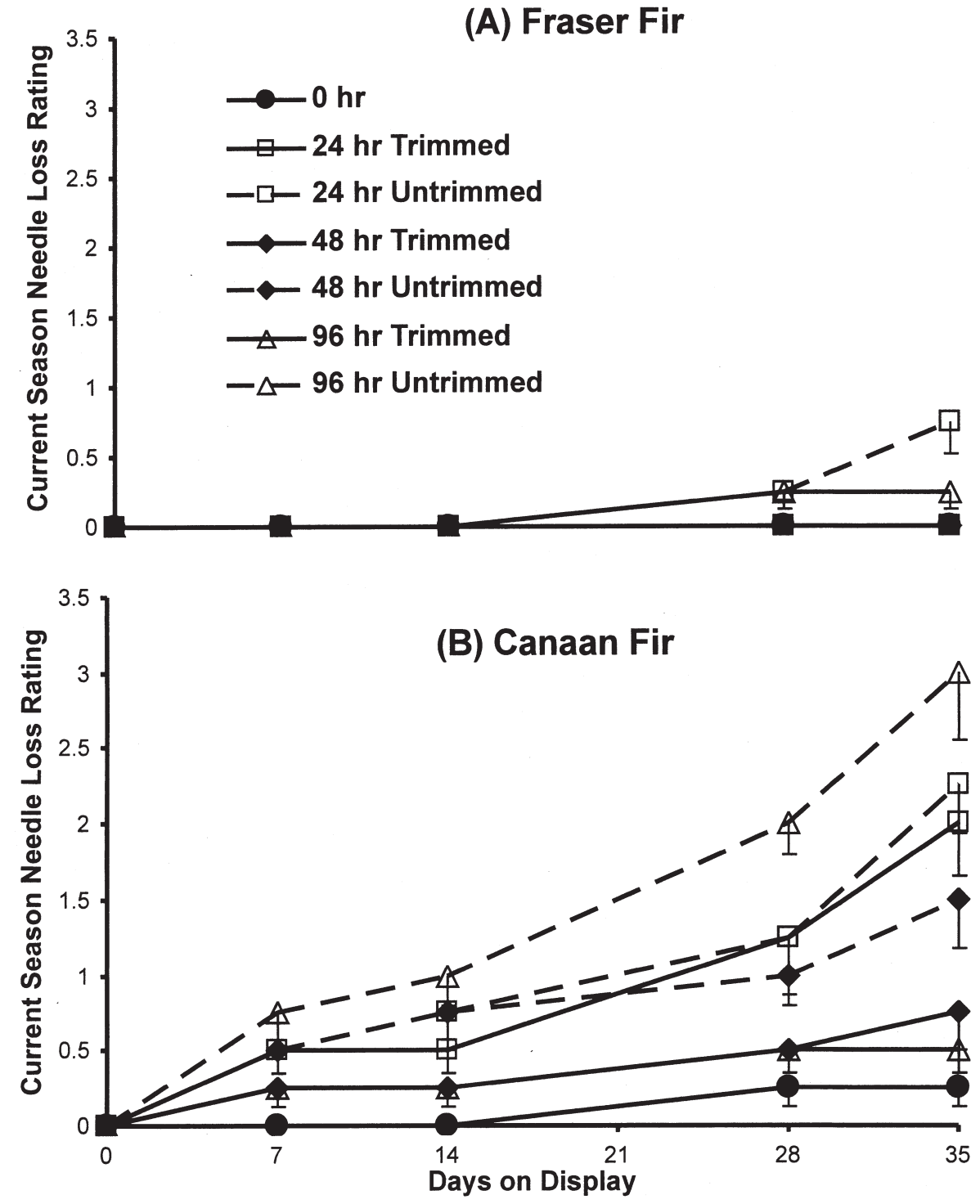

Fig. 2. Effect of storage duration and stem trimming on current season needle retention of fraser fir and canaan fir. Needle loss was measured on a 0 to 10 scale, where $0=$ none and $10=91 \%$ to $100 \%$. Bars represent SE of four replications.

pressure deficit, temperature, and light affect postharvest drying of fraser fir and eastern white pine. HortScience 26:402-405.

Hinesley, L.E. and L.K. Snelling. 1997. Drying and rehydration of atlantic white cedar, arizona cypress, eastern white pine, leyland cypress, and virginia pine Christmas trees. HortScience 32:1252-1254.

Mitcham-Butler,E.J., L.E. Hinesley, and D.M. Pharr. 1988. Effect of harvest date, storage temperature, and moisture status on postharvest needle retention of fraser fir. J. Environ. Hort 6:1-4.

Montano, J.M. and W.M. Proebsting. 1985. Effects of drying on cut douglas-fir. J. Amer. Soc. Hort. Sci. 110:751-757.
Seiler, J.R, T.J. Nichols, and D.J. Paganelli. 1988. Rehydration characteristics of cut white pine and norway spruce Christmas trees. HortScience 23:164-166.

Sidebottom, J.R. 2001. Phytophthora root rot. Christmas Trees 28:6-8.

Tompkins, D. 2000. Looking forward-views from the Northeast. Amer. Christmas Tree J. 44(1):12-15.

U.S. Department of Agriculture. 1989. United States standards for grades of Christmas trees: Revised, effective 30 Oct. 1989. U.S. Dept. Agr., Agr. Mktg. Serv., Wash., D.C. [FR Doc. 89-23043]. 